\title{
PRENATAL PSYCHOLOGY ASPECT OF PARENTING
}

Savchenko Yuriy, PhD, Associate Professor, Deputy Director of the Pedagogical Institute of Borys Grinchenko Kyiv University, Shamo str. 18/2, 02154 Kyiv, Ukraine, y.savchenko@kubg.edu.ua

The article discloses the modern womanhood readiness aspects to maternity. The author defines that women ready for maternity have got a sympathetic mother image that perceives and promotes the child's development and education, sharing her self-worthiness. The article gives the men and women's psychological characteristics analysis during the pregnancy according to the pregnancy dividing into the major trimester based on physiological views. Pregnant women have differences in behavior and attitude. Some of them change their image completely, when others remain unchanged in their character and behavior. Every woman becomes a mother, in her own way but with the extremes exception that is common for mothers to have their special psychology, which changes every month. The article emphasizes the main modern pregnant women's motives that mainly depend on the women's personal attitudes and social norms, which are determined by cultural and historical time when they live. The motivational background experiences varieties of pregnancy are selected for manifestation the fact that for most women pregnancy is not only conscious desire, the essential spiritual meaning of maternity, but also in major sense as the neediness of conformity to social requirements. The proposed program for pregnant women`s psychological preparation to childbirth «Happy mother - happy baby», to form a conscious positive perception of maternity and implementation of educational and health issues solving.

This program is aimed to raise maternity feelings by the means of forming spiritual connection between mother and child inside her; awareness of life plots and work with pregnant woman's personal meanings and values; the psychological correction of the women's emotional states, relieving stress and creating a comfortable environment during pregnancy on the emotional, psychophysical and psychophysiological level.

Key words: childbirth; maternity; paternity; pregnancy; prenatal development; relaxation.

Стаття надійшла до редакції 05.05.2016

Прийнято до друку 26.05.2016

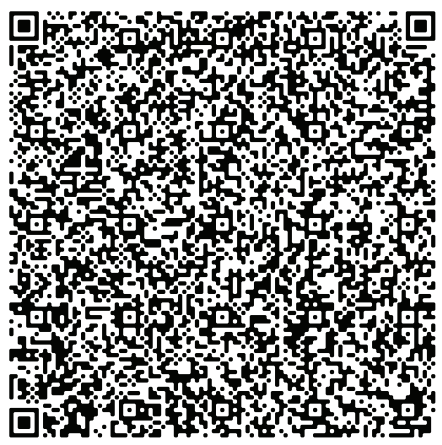

\section{ОСОБЛИВОСТІ ФОРМУВАННЯ ДОВІЛЬНОЇ ПОВЕДІНКИ У ДІТЕЙ СТАРШОГО ДОШКІЛЬНОГО ВІКУ}

У даній статті презентовано авторську програму розвитку довільної поведінки дітей старшого дошкільного віку шляхом оптимізаціі їхніх емоційних переживань та батьківсько-дитячих стосунків. Складовими програми є методологічний, практичний, діагностичний блоки. До методологічного блоку входить мета, методологічні підходи, принципи, завдання програми. Практичний блок описує зміст, форми, методи і прийоми програми розвитку довільної поведінки дітей старшого дошкільного віку. Діагностичний блок містить процедуру, зміст, методи і прийоми оцінювання результатів реалізацї цієї програми. Запропоновано тематику комплексних занять з означеної програми.

Ключові слова: довільна поведінка дошкільника, довільність емоційної регулящї дошкільника, батьківськодитячі стосунки.

Вступ. Сучасна система освіти грунтується на засадах гуманно-особистісного підходу і потребуе дослідження низки психолого-педагогічних про- блем, серед яких вагоме місце належить вивченню проблеми волі та їі розвитку у дітей дошкільного віку. Для розуміння природи і генези вольових 
явищ, можливостей їх прогнозування в розвитку постає необхідність дослідження таких явищ на ранніх стадіях онтогенезу людини, зокрема в дошкільному віці. Особливе місце в цьому процесі належить розвитку довільної поведінки дитини старшого дошкільного віку як стрижня їі особистісного зростання.

Важливого значення для розвитку довільної поведінки дітей старшого дошкільного віку відводять батькам та іншим найближчим авторитетним людям дитини. Діти наслідують батьківську форму поведінки у сім’і, підсвідомі реакції, різноманітні позитивні чи негативні емоції, значущі особливості подружніх стосунків. Ставлення батьків до дитини та стилю сімейного виховання у формуванні особливостей психіки та поведінки дошкільника підкреслювалося в дослідженнях О. М. Байєр (Байєр О. М., 2005), А. М. Казьмина (Казьмин А. М., Коновко Н. А., Сальникова О. Г., Тупицина Е. К., Федина Е. В., 2014), О. Л. Кононко (Кононко О. Л., 2003), В. У. Кузьменко (Кузьменко В. У., 2005), Т. О. Піроженко (Піроженко Т. О., Хартман О. Ю., 2014) та інших.

Підставою для розробки даної програми стали результати вивчення рівня сформованості довільної поведінки дітей старшого дошкільного віку на базі дошкільного навчального закладу (ясла-садок) комбінованого типу «Лісова казка» м. Бровари Київської області та дошкільних навчальних закладів м. Глухова Сумської області - дошкільний навчальний заклад (ясла-садок) «Чебурашка», дошкільний навчальний заклад (центр розвитку дитини) «Світлячок». Дослідно-експериментальною роботою було охоплено 100 повних родин, які складалися з 200 дорослих обох статей і 100 дітей. Якісний та кількісний аналізи показали, що у більшості старших дошкільників наявний середній рівень розвитку довільної поведінки старших дошкільників (54 \%) та низький рівень (34 \%) який потребував корекційної роботи.

Мета статті - висвітлення змісту авторської програми розвитку довільної поведінки дітей старшого дошкільного віку.

Принципи організації програми розвитку довільної поведінки старших дошкільників. Під час визначення цілей та завдань нашої роботи з дітьми, а також добірки конкретних методів ми виходили 3 основних принципів розвитку, розроблених на основі вчення про закономірності й рушійні сили психічного розвитку дитини у працях Л. Виготського, Л. Божович, Д. Ельконіна, О. Запорожця, Г. Костюка, О. Леонтьєва та ін.

По-перше, це принцип нормативності розвитку, який передбачає існування певної «вікової норми» розвитку, своєрідного вікового еталону.

По-друге, принцип системності розвитку. Його реалізація в роботі забезпечує спрямованість на усунення причин і джерел відхилення. Оскільки розви- ток довільної поведінки відбувається здебільшого у процесі взаємин дитини з батьками, то наша робота була спрямована на гармонізацію цих взаємин.

По-третє, діяльнісний принцип, який визначає вибір засобів та конкретних методів впливу на дітей і дорослих.

По-четверте, принцип активного залучення батьківта інших значущих осіб в оточенні дитини до реалізації завдань розвивальної роботи. Система стосунків дошкільника з близькими дорослими, особливості спілкування, способи і форми взаємодії є важливим компонентом соціальної ситуації розвитку дитини, багато в чому визначають зону їі найближчого розвитку.

Умови організації програми розвитку довільної поведінки старших дошкільників. Нормативні показники розвитку волі досягаються за умови цілеспрямованої психолого-педагогічної роботи 3 дітьми; формування цілеспрямованості, усвідомленості, опосередкованості дій дитини досягається окремими завданнями; для розвитку цілеспрямованості зусилля слід спрямовувати насамперед на необхідність виконувати інструкції дорослого, після чого - на самостійну постановку цілей та їх досягнення.

Зміст і процедура реалізації програми розвитку довільної поведінки дітей старшого дошкільного віку. Підставою для розробки даної програми слугували отримані дані під час спостереження і бесіди з дітьми, а також результати таких досліджень, як: методики Р. Жиля, Квітки восьмицвітки, методики вивчення індивідуальних особливостей розвитку вольової поведінки старших дошкільників (за схемою Л. Соловйової, «РARI» і «Тесту-опитувальника батьківського ставлення», модифікованої анкети для батьків О. Байєр. в яких відображено уявлення дітей та позиції батьків у системі батьківсько-дитячих стосунків. Зміст даної програми представлений на Рис. 1.

Дана програма складається з 17 комплексних, розвивальних занять з елементами тренінгової роботи для батьків. Комплексні заняття корекції і розвитку особистості дошкільника побудовані з урахуванням єдності розумового і емоційного (когнітивного i афективного), зовнішнього і внутрішнього компонентів психічного розвитку дитини. Тематика даних занять представлено в Таблиці 1.

Технологічний інваріант полягав у тому, що матеріал було побудовано на основі психологічних закономірностей розвитку, становлення свідомості дитини.

Заняття передбачали творче самовираження дітей і батьків. Діти поступово відкривались і поетапно засвоювали засоби самовираження через гру, казки, живопис і починали використовувати їх, створюючи свої власні маленькі шедеври. Розвиток здібностей відбувся через формування понять на основі змістових узагальнень. Запам'ятовувати все не вимагалося, було важливо, щоб кожна дити- 


\section{МЕТОДОЛОГІЧНИЙ БЛОК}

Мета: оптимізація емоційних переживань і довільної поведінки старших дошкільників та батьківськодитячих стосунків в умовах сім’і

Методологічні підходи: особистісно-орієнтований, системно діяльнісний, функціональний

Принципи: нормативності розвитку, системності розвитку, діяльнісний, активного залучення батьків та інших значущих осіб в оточенні дитини до розвивальної роботи

Завдання: ознайомлення батьків із мінімумом потрібних знань про емоційні переживання і довільну поведінку дітей дошкільного віку та умови їхнього розвитку у системі батьківсько-дитячої взаємодії; ознайомлення батьків з ефективними методиками розвитку довільної поведінки дошкільника; активізація виховного потенціалу сім'ї шляхом включення обох батьків у процес виховання власної дитини; впровадження у практику сімейного виховання спільних - батька і матері - підходів до виховання відповідної, самостійної, емоційно благополучної дитини.

\begin{tabular}{|c|c|c|c|}
\hline \multicolumn{4}{|c|}{ ПРАКТИЧНИЙ БЛОК } \\
\hline Процедура & Зміст & Форми & Методи і прийоми \\
\hline $\begin{array}{l}\text { Реалізація програми } \\
\text { розвитку довільної } \\
\text { поведінки дітей } \\
\text { дошкільного віку. }\end{array}$ & $\begin{array}{l}\text { - розширення можливостей } \\
\text { розуміння батьками своєї дитини; } \\
\text { - підвищення рефлексії батьків у } \\
\text { взаємовідносинах з дитиною; } \\
\text { - вироблення нових навичок } \\
\text { взаємодії з дитиною; } \\
\text { - активізація комунікації в сім’ї. }\end{array}$ & $\begin{array}{l}\text { Індивідуальні, } \\
\text { групові. }\end{array}$ & $\begin{array}{l}\text { - бесіда; } \\
\text { - смислові діалоги; } \\
\text { - ігрова терапія; } \\
\text { - імаготерапія } \\
\text { (терапія образами); } \\
\text { - арттерапія; } \\
\text { Психогімнастика. } \\
\end{array}$ \\
\hline \multicolumn{4}{|c|}{ дІАГНОСТИЧНИЙ БЛОК } \\
\hline Процедура & Зміст & Форми роботи & Методи і прийоми \\
\hline $\begin{array}{l}\text { - діагностика } \\
\text { емоційних станів } \\
\text { дитини; } \\
\text { - діагностика } \\
\text { довільності } \\
\text { поведінкових } \\
\text { проявів старших. }\end{array}$ & $\begin{array}{l}\text { - малюнковий тест «Малюнок сім’ї } \\
\text { (Т. Хоментаускас); } \\
\text { - методика «Квітка-Восьмицвітка» } \\
\text { (С. Велієва); } \\
\text { - проективна методика дослідження } \\
\text { особистості Р. Жиля; } \\
\text { - методика вивчення індивідуальних } \\
\text { особливостей. } \\
\end{array}$ & $\begin{array}{l}\text { Індивідуальні, } \\
\text { групові. }\end{array}$ & $\begin{array}{l}\text { - методи } \\
\text { математичної ста- } \\
\text { тистики; } \\
\text { - якісний аналіз. }\end{array}$ \\
\hline $\begin{array}{l}\text { - дошкільників; } \\
\text { - діагностика } \\
\text { міжособистісних } \\
\text { стосунків у сім'ї. }\end{array}$ & $\begin{array}{l}\text { - розвитку вольової поведінки стар- } \\
\text { ших дошкільників (Л. Соловйова); } \\
\text { - методика РАRI Е. Шефер і } \\
\text { Р. Белл, адаптована Т.Нещерет; } \\
\text { - тест-опитувальник батьківського } \\
\text { ставлення (Г. Варга, В. Столін); } \\
\text { - модифікована анкета для батьків } \\
\text { О. Байєр. }\end{array}$ & & \\
\hline
\end{tabular}

\section{Рuc. 1. Програма розвитку довільної поведінки дітей старшого дошкільного віку}

на могла вибрати те, що ії цікавить, близьке їй, щоб вона змогла знайти себе.

Висновки. Отже, організація розвивального середовища у процесі впровадження програми засобів ефективного впливу на емоційні переживання дітей старшого дошкільного віку під час їхньої взаємодії з дорослими дала змогу посилити оптимізацію міжособистісних стосунків дитини з дорослими, що сприяло розвиткові довільної поведінки дитини.

Завдяки постійній стимуляції інтересу до спільної діяльності з дорослими і здійснювався не тіль- ки процес становлення емоційного компонента, а й відбувалося набуття дитиною відповідних знань (когнітивний компонент), та вмінь поєднувати емоції з дією (поведінковий компонент), що сприяло гармонійному розвиткові довільної поведінки.

Проведене дослідження не вичерпує всіх аспектів означеної проблеми. Перспективи подальших досліджень вбачаються у вивченні впливу самооцінки дитини на формування довільної поведінки в умовах сім'ї і можливості психологопедагогічно впливу на ці процеси. 
Таблиця 1.

Тематика комплексних занять з означеної програми

\begin{tabular}{|c|c|c|c|}
\hline $\begin{array}{l}\text { № } \\
3 / \Pi\end{array}$ & Тема заняття & Мета заняття & $\begin{array}{c}\text { Час } \\
\text { проведення }\end{array}$ \\
\hline 1 & $\begin{array}{l}\text { «Світ дитячий і світ до- } \\
\text { рослий». }\end{array}$ & $\begin{array}{l}\text { Розширити уявлення батьків про відмінності між світом дитини і доросло- } \\
\text { го, що простежується в особливостях сприйнятя, емоційних переживань, } \\
\text { мотивації поведінки. Набуття навичок аналізу причин поведінки дитини, } \\
\text { виходячи з позиції дитини. }\end{array}$ & Вересень \\
\hline 2 & «Знайомство з собою». & $\begin{array}{l}\text { Привернути увагу дітей до власної особистості, формувати адекватне уявлен- } \\
\text { ня про образ тіла, розвивати почуття індивідуальності, власної значущості, } \\
\text { самоповаги. Вчити зв'язно, послідовно висловлювати свої думки. }\end{array}$ & Вересень \\
\hline 3 & «Подорож до себе». & $\begin{array}{l}\text { Продовжити знайомство з власним «Я», розвивати почуття своєї } \\
\text { значущості, самоцінності, індивідуальності, творчі здібності, мислення, } \\
\text { комунікативні навички. }\end{array}$ & Вересень \\
\hline 4 & $\begin{array}{l}\text { «Мова прийняття» і } \\
\text { «мова неприйняття». }\end{array}$ & $\begin{array}{l}\text { Ознайомити батьків з поняттями «прийняття» дитини, особливостями } \\
\text { приймаючої і не приймаючої поведінки батьків. Визначення «мови при- } \\
\text { йняття» і «мови неприйняття». }\end{array}$ & Жовтень \\
\hline 5 & «Острів мого Я». & $\begin{array}{l}\text { Продовжити знайомство зі своїм «Я». Вчити розуміти і відчувати свій } \\
\text { внутрішній світ, своє ставлення до себе і до оточуючих людей: вміти радіти } \\
\text { з того, що ти такий, яким ти є. Розвивати уяву, творчість, зв’язне мовлення. } \\
\text { Виховувати повагу один до одного. }\end{array}$ & Жовтень \\
\hline 6 & «Стежинкою добра». & $\begin{array}{l}\text { Продовжити вчити відчувати і розуміти свій внутрішній світ, своє ставлен- } \\
\text { ня до себе і до оточуючих. Виховувати добрі почуття, взаємоповагу. Роз- } \\
\text { вивати механізми децентрації, емпатію, уяву, мислення, зв’язне мовлення. }\end{array}$ & Жовтень \\
\hline 7 & $\begin{array}{l}\text { «Проблеми дітей та } \\
\text { батьків. Активне слухан- } \\
\text { ня як спосіб вирішення } \\
\text { проблем дітей». }\end{array}$ & $\begin{array}{l}\text { Пояснити відмінність проблем батьків і проблем дітей; познайомити з } \\
\text { цілями і прийомами активного слухання, розвити навички активного слу- } \\
\text { хання. }\end{array}$ & Листопад \\
\hline 8 & «Посмішка нас зігріває». & $\begin{array}{l}\text { Дати дітям знання про настрій веселий, сердитий, здивований, ображений, } \\
\text { сумний. Розвивати спостережливість, вміння коригувати свою поведінку. } \\
\text { Продовжувати вчити дітей краще розуміти себе, отримувати задоволення } \\
\text { в суспільних відносинах. Виховувати любов і взаємоповагу до оточуючих, } \\
\text { почуття безпеки. }\end{array}$ & Листопад \\
\hline 9 & $\begin{array}{l}\text { «Спільне } з \text { дітьми за- } \\
\text { няття». }\end{array}$ & $\begin{array}{l}\text { Визначити «вузькі зони» взаємодії батьків та дітей, створити ситуації } \\
\text { взаємної дії та співпраці. Ознайомити батьків } з \text { дітьми (опис батьків «очи- } \\
\text { ма» дітей). }\end{array}$ & Грудень \\
\hline 10 & $\begin{array}{l}\text { «Разом нам не буває } \\
\text { сумно». }\end{array}$ & $\begin{array}{l}\text { Спонукати дітей до моральних переживань щодо оточуючих. Продовжи- } \\
\text { ти роботу з усвідомлення гами вміння виявляти добрі почуття. Створю- } \\
\text { вати психологічну атмосферу комфортності, захищеності. Удосконалюва- } \\
\text { ти навички інтерактивного спілкування. Розвивати мислення, фантазію, } \\
\text { творчість, уміння правильно висловлювати свої думки. }\end{array}$ & Грудень \\
\hline 11 & $\begin{array}{l}\text { «одорож до країни } \\
\text { внутрішнього Я». }\end{array}$ & $\begin{array}{l}\text { Продовжувати розвивати у дитини рефлексивні навички, відчувати і } \\
\text { усвідомлювати свій внутрішній світ, почуття індивідуальності. Вияви- } \\
\text { ти особливості самооцінки, провести вправи, спрямовані на корекцію } \\
\text { заниженої самооцінки. Удосконалювати комунікативні навички, уміти } \\
\text { розуміти іншого, здатність відчувати теплі почуття стосовно до інших, по- } \\
\text { вагу до них. Розвивати уяву, творчість, зв'язне мовлення. }\end{array}$ & Грудень \\
\hline 12 & «Проблеми батьків». & $\begin{array}{l}\text { Навчити батьків різних способів єфективної комунікації для розширення } \\
\text { проблем, які можуть виникнути у батьків } 3 \text { дітьми. }\end{array}$ & Січень \\
\hline 13 & $\begin{array}{l}\text { «Сходинка } \\
\text { терплячості». }\end{array}$ & $\begin{array}{l}\text { Продовжувати формувати в дітей почуття любові, добра, поваги до ото- } \\
\text { чуючих, позитивну самооцінку. Розвивати обережне, дбайливе, доброзич- } \\
\text { ливе ставлення до інших людей. Вчити розуміти цінності свого життя і } \\
\text { чужого, відповідальності за збереження життя. Вчити зв'язано, послідовно } \\
\text { висловлювати свої думки, розвивати уяву, творчість, відчуття схвалення та } \\
\text { розуміння, поваги до себе та до інших. }\end{array}$ & Січень \\
\hline 14 & «Конфлікти». & $\begin{array}{l}\text { Визначити способи вирішення конфліктних ситуацій, знайомство з } 6 \text { кро- } \\
\text { ками безпрограшного методу розв'язання конфліктів (за Т. Гордоном). }\end{array}$ & Січень \\
\hline 15 & $\begin{array}{l}\text { «Заохочення і покаран- } \\
\text { ня». }\end{array}$ & $\begin{array}{l}\text { Ознайомити батьків з принципами використання заохочення та покаран- } \\
\text { ня. }\end{array}$ & Лютий \\
\hline 16 & «Важкий випадок». & $\begin{array}{l}\text { Підвищення компетентності батьків в вирішенні } \quad \text { труднощів під } \\
\text { часспілкування з дитиною, усвідомлення особистісних проблем, блокуючи } \\
\text { розуміння характеру взаємодії з іншими людьми. }\end{array}$ & Лютий \\
\hline
\end{tabular}




\section{Література}

1. Байєр О. $\boldsymbol{M}$. Розвиток психічної саморегуляції старших дошкільників у різних видах доступної дитині довільної активності / О. М. Байєр // Социальные технологии: актуальные проблемы теории и практики: Межд. межвуз. сб. научн. работ. - К.- Запорожье - Одесса: КНУ им. Т. Шевченко, ОНУ им. И. И. Мечникова, ЗНУ, ГУ «ЗИГМУ», 2005. - Вып. 26. - 20 с.

2. $\boldsymbol{\kappa a з ъ м и н ~} \boldsymbol{A} . \boldsymbol{M}$. Шкала эмоционального неблагополучия и атипичного поведения дошкольников / А. М. Казьмин, Н. А. Коновко, О. Г. Сальникова, Е. К. Тупицина, Е. В. Федина [Электронный ресурс] // Клиническая и специальная психология, 2014. - Том 3. - № 3. - Режим доступа: http://psyjournals.ru/ psyclin/2014/n3/Kazmin_et_al_1.shtml, DOI: http://dx.doi.org/10.17759/cpse.

3. Кононко О. Л. Активність як провідна характеристика особистісного становлення дошкільника / Олена Леонтіївна Кононко // Теорет.-метод. проблеми виховання дітей та учн. молоді: зб. наук. праць. / Ін-т проблем виховання АПН України. - Київ; Житомир, 2003. - Вип. 5, кн. 1. - 29 с.

4. Кузьменко В. У. Розвиток індивідуальності дитини 3-7 років: монографія / В. У. Кузьменко. - К.: НПУ ім. М. П. Драгоманова, 2005.- 354 с.

5. Піроженко Т. О. Виховуємо дитину - зростаємо як батьки: навч.-метод. посіб. / Т. О. Піроженко, О. Ю. Хартман. - Тернопіль: Мандрівець, 2014. - 168 с.

\section{ОСОБЕННОСТИ ФОРМИРОВАНИЯ ПРОИЗВОЛЬНОГО ПОВЕДЕНИЯ У ДЕТЕЙ СТАРШЕГО ДОШКОЛЬНОГО ВОЗРАСТА}

Теплюк Анна, кандидат психологических наук, преподаватель кафедры педагогики и психологии Педагогического института, Киевский университет имени Бориса Гринченка, бул. И. Шамо 18/2, 02154 г. Киев, Украина, a.tepliuk@kubg.edu.ua

В данной статье представлено авторскую программу развития произвольного поведения детей старшего дошкольного возраста путем оптимизации их эмоциональных переживаний и родительско-детских отношений. Составляющими программы является методологический, практический, диагностический блоки. К методологического блока входит чель, методологческие подходы, принципы, задачи программы. Практический блок описывает содержание, формы, методы и приемы программы произвольного поведения детей старшего доикольного возраста. Диагностический блок содержит процедуру, содержание, методы и приемы оценки результатов реализации этой программы. Предложено тематику комплексных занятий по указанной программы.

Ключевые слова: произвольное поведение дошкольника; произвольность эмоциональной регуляции дошкольника; родительско-детские отношения.

\section{FEATURES OF ARBITRARY BEHAVIOR IN PRESCHOOL CHILDREN}

Tepliuk Anna, PhD, Lecturer of the Department of Pedagogy and Psychology of Pedagogical Institute, Borys Grinchenko Kyiv University, Shamo Str. 18/2, 02154 Kyiv, Ukraine, a.tepliuk@kubg.edu.ua

In this article the author presented the program of development of arbitrary behavior of preschool children by optimizing their emotional experiences and parent-child relationships. The components of the program are methodological, practical, diagnostic blocks. By methodological unit is objective, methodical approaches, principles and objectives. Practical unit describes the contents, forms, methods and techniques of application of arbitrary behavior of children under school age. The diagnostic block contains the procedure, content, methods and techniques for measuring the results of this program. The main objective of this program was to: review the parents of minimum required knowledge of emotional distress, arbitrary behavior of preschool children and their conditions of system parent-child interaction; familiarize parents with effective methods of arbitrary behavior of preschoolers; intensification of the educational potential of family by including both parents in the upbringing of their own children; implementation in practice of family education together - father and mother - appropriate approaches to education, independent, emotionally happy child.

A complex subject classes the designated program. Subjects consisted of 17 complex, developmental classes with elements of training for parents. Complete correction classes and personal development preschooler constructed on the basis of unity of mental and emotional (affective and cognitive), internal and external components of the mental development of children.

Key words: arbitrary behavior preschooler; arbitrariness of emotional regulation preschooler; parent-child relationship. 